\title{
ANALISIS KALIMAT MAJEMUK BAHASA INDONESIA DALAM TEKS ILMIAH SEBAGAI BAHAN PENGAYAAN MATA KULIAH SINTAKSIS
}

\author{
Oleh \\ Hendrik Jehane, Simon Sabon Ola, Alex Djawa, Anastasia Leda, Adventura Lamawato, \\ Priska Kusumawardani Napa Maol, Maria N. Gabir, Darius Iku \\ FKIP Universitas Nusa Cendana
}

\begin{abstract}
Abstrak
Penelitian ini dilakukan untuk mewujudkan bahan pembelajaran berbasis penelitian. Yang dimaksudkan bahan pembelajaran berbasis penelitian adalah bahan pembelajaran yang dikembangkan berdasarkan hasil penelitian atau pengkajian ilmiah yang dilakukan oleh dosen itu sendiri. Dengan demikian, bahan pembelajaran yang baik adalah produk penelitian ilmiah yang dilakukan oleh dosen sendiri, bukan hanya hasil kompilasi dari buku-buku yang ditulis oleh para ahli sebelumnya.

Masalah penelitian ini adalah: (1) Bagaimanakah struktur kalimat majemuk dalam teks ilmiah? (2) Bagaimanakah hubungan antarklausa dalam kalimat majemuk bahasa Indonesia dalam teks ilmiah? Tujuan penelitian ini adalah (1) untuk mengeksplanasikan struktur kalimat majemuk dalam teks ilmiah, (2) untuk memaparkan hubungan antarklausa dalam kalimat majemuk bahasa Indonesia yang terdapat dalam teks ilmiah.

Jenis penelitian yang digunakan adalah penelitian deskriptif. Penelitian deskriptif adalah penelitian yang bertujuan untuk mendeskripsikan suatu fenomena sebagaimana adanya pada waktu penelitian. Pendekatan yang dipakai dalam penelitian ini adalah pendekatan kualitatif. Penelitian kualitatif berusaha mengungkap gejala secara menyeluruh dan sesuai dengan konteks (holistik-kontekstual) melalui pengumpulan data dari latar alami dengan memanfaatkan diri peneliti sebagai instrumen kunci.

Hasil penelitian menemukan kalimat majemuk dalam teks ilmiah terdiri atas tiga macam yaitu kalimat majemuk koordinatif, kalimat majemuk subordinatif, dan kalimat majemuk kompleks. Kalimat majemuk koordinatif ada yang terdiri atas dua klausa dan ada pula yang terdiri atas 3 klausa. Kalimat majemuk subordinatif dalam teks ilmiah ada yang terdiri atas dua klausa dan ada pula yang terdiri atas tiga klausa. Struktur kalimat majemuk subordinatif terdiri atas lima tipe. Struktur kalimat majemuk kompleks terdiri atas 7 tipe.

Terdapat tiga macam hubungan semantik antarklausa dalam kalimat majemuk koordinatif bahasa Indonesia dalam teks ilmiah, yaitu: (1) hubungan perlawanan, (2) pemilihan, dan (3) penjumlahan/penambahan. Terdapat empat macam hubungan antarklausa dalam kalimat majemuk subordinatif dalam teks ilmiah, yaitu: (1) hubungan tujuan, (2) hubungan syarat, (4) hubungan atributif, dan hubungan penyebaban. Ditemukan tujuh macam hubungan antarklausa dalam kalimat majemuk kompleks, yaitu: (1) hubungan penjelasan, (2) hubungan konsesif, (3) hubungan syarat, (4) hubungan penyebaban, (5) hubungan atributif, (6) hubungan akibat, dan (7) hubungan tujuan.
\end{abstract}

Kata Kunci: kalimat majemuk, teks ilmiah, struktur kalimat majemuk, hubungan antarklausa, kalimat majemuk koordinatif, kalimat majemuk subordinatif, dan kalimat majemuk kompleks. 


\section{Abstract}

This research was conducted to realize research-based learning materials. What is meant by research-based learning materials are learning materials developed based on the results of research or scientific studies conducted by the lecturers themselves. Thus, good learning materials are the product of scientific research carried out by the lecturers themselves, not just the compilation of books written by previous experts.

The research problems are: (1) What is the structure of compound sentences in scientific texts? (2) What is the relationship between clauses in Indonesian compound sentences in scientific texts? The aims of this study are (1) to explain the structure of compound sentences in scientific texts, (2) to explain the relationship between clauses in Indonesian compound sentences contained in scientific texts.

The type of research used is descriptive research. Descriptive research is research that aims to describe a phenomenon as it is at the time of the study. The approach used in this research is a qualitative approach. Qualitative research seeks to reveal the symptoms as a whole and in accordance with the context (holistic-contextual) through collecting data from natural settings by using the researcher himself as a key instrument.

The results of the study found that there are three kinds of compound sentences in scientific texts, namely coordinating compound sentences, subordinate compound sentences, and complex compound sentences. Some coordinating compound sentences consist of two clauses and some consist of 3 clauses. Subordinating compound sentences in scientific texts consist of two clauses and some consist of three clauses. Subordinating compound sentence structure consists of five types. Complex compound sentence structure consists of 7 types.

There are three kinds of semantic relationships between clauses in Indonesian coordinative compound sentences in scientific texts, namely: (1) resistance relations, (2) selection, and (3) addition/addition. There are four kinds of inter-clause relationships in subordinating compound sentences in scientific texts, namely: (1) objective relationship, (2) conditional relationship, (4) attributive relationship, and causal relationship. There are seven kinds of inter-clause relationships in complex compound sentences, namely: (1) explanatory relationship, (2) concessional relationship, (3) conditional relationship, (4) causal relationship, (5) attributive relationship, (6) effect relationship, and (7) relationship goals.

Keywords: compound sentence, scientific text, compound sentence structure, inter-clause relationship, coordinating compound sentence, subordinate compound sentence, and complex compound sentence

\section{PENDAHULUAN}

\subsection{Latar Belakang}

Penelitian ini berkaitan dengan mata kuliah Sintaksis yang diasuh oleh peneliti. Mata kuliah Sintaksis terdiri atas tiga pokok bahasan utama, yaitu (1) frasa, (2) klausa, dan (3) kalimat. Pokok bahasan kalimat terdiri atas beberapa subpokok bahasan; salah satu subpokok bahasan adalah kalimat majemuk. Kalimat majemuk adalah kalimat yang terdiri atas dua atau lebih klausa. Berdasarkan sifat hubungan semantis antarklausa dalam kalimat majemuk, terdapat hubungan koordinatif dan hubungan subordinatif. Berdasarkan sifat hubungan tersebut, umumnya para ahli bahasa membedakan kalimat majemuk atas dua macam yakni 
kalimat majemuk koordinatif/setara dan kalimat majemuk subordinatif/bertingkat. Disebut kalimat majemuk koordinatif apabila hubungan antarklausa di dalamnya bersifat koordinatif. Kalimat majemuk subordinatif apabila hubungan antarklausa di dalamnya bersifat subordinatif.

Sudah banyak ahli bahasa yang membahas kalimat mejemuk dalam buku tata bahasa Indonesia atau buku sintaksis. Data yang mereka gunakan sebagai contoh pada umumnya tidak berasal dari pengunaan bahasa yang alamiah. Sebagian contoh merupakan kalimat rekaan. Kebetulan sebagian besar ahli bahasa tersebut adalah penutur bahasa Indonesia sehingga mereka lebih banyak menggunakan intuisi. Kalaupun ada contoh kalimat yang yang diangkat dari penggunaan bahasa yang nyata, umumnya berupa bahasa percakapan atau kisahan yang berasal dari teks fiksi (novel atau cerpen). Kalimat majemuk yang digunakan sebagai contoh pada umumnya terdiri atas dua atau tiga klausa. Dalam kenyataannya kalimat mejemuk tidak sesederhana itu. Kalimat majemuk dalam tes ilmiah ilmiah dan teks jurnalistik bisa mencapai enam klausa dan mencerminkan hubungan antarklausa yang sangat kompleks.

Penelitian ini akan difokuskan pada kalimat majemuk yang digunakan di dalam teks ilmiah. Kalimat majemuk dalam teks ilmiah sangat produktif. Hasil penelitian ini diharapkan dapat memberikan gambaran mengenai struktur dan hubungan antarklausa dalam kalimat majemuk bahasa Indonesia yang nyata digunakan dalam teks ilmiah, bukan rekaan yang bersifat intuitif.

Penelitian ini dilakukan untuk mewujudkan bahan pembelajaran berbasis penelitian. Yang dimaksudkan bahan pembelajaran berbasis penelitian adalah bahan pembelajaran yang dikembangkan berdasarkan hasil penelitian atau pengkajian ilmiah yang dilakukan oleh dosen itu sendiri. Dengan demikian, bahan pembelajaran yang baik adalah produk penelitian ilmiah yang dilakukan oleh dosen sendiri, bukan hanya hasil kompilasi dari buku-buku yang ditulis oleh para ahli sebelumnya.

Dalam rangka mewujudkan bahan pembelajaran Sintaksis berbasis penelitian ini, peneliti telah melakukan beberapa penelitian dan telah dimuat dalam jurnal ilmiah, antara lain

\begin{tabular}{llll}
\multicolumn{1}{c}{ Judul } & Jurnal ilmiah \\
1) & Inkorporasi dengan Pelesapan Verba dalam & 1996 & Linguistika \\
& Bahasa Indonesia & & \\
2) & Struktur Argumen dan Peran Tematik Kalimat & & Guru Bahasa \\
& Bahasa Indonesia & 1998 & Guru Bahasa \\
3) Inkorporasi Objek dan Oblik dalam Bahasa Indonesia & 2000 & \\
4) Relasi Gramatikal Bahasa Indonesia: Suatu & & Guru Bahasa \\
& Tinjauan & 2003 & Bahasa \& Sastra \\
5) Posisi Keterangan dalam Kalimat Bahasa Indonesia & 2006 & Bahasa \& Sastra \\
6) Kontroversi Sistem Diatesis Bahasa Indonesia & 2007 &
\end{tabular}

\subsection{Permasalahan}

Sesuai latar belakang masalah di atas, masalah penelitian ini dirumuskan sebagai berikut.

1) Bagaimanakah struktur kalimat majemuk bahasa Indonesia dalam teks ilmiah?

2) Bagaimanakah hubungan makna antarklausa dalam kalimat majemuk bahasa Indonesia dalam teks ilmiah? 


\subsection{Tujuan Penelitian}

Tujuan penelitian ini adalah:

1) untuk mengeksplanasikan struktur kalimat majemuk bahasa Indonesia dalam teks ilmiah,

2) untuk memaparkan hubungan antarklausa di dalam kalimat majemuk bahasa Indonesia dalam teks ilmiah.

\subsection{Manfaat Penelitian}

Penelitian ini diharapkan bermanfaat untuk:

1) menambah referensi sintaksis bahasa Indonesia;

2) pengayaan bahan ajar mata kuliah Sintaksis bagi mahasiswa Program Studi Pendidikan Bahasa dan Sastra Indonesia.

\section{TINJAUAN PUSTAKA}

Setiap buku tata bahasa Indonesia dan buku-buku sintaksis atau tata kalimat bahasa Indonesia pasti membahas kalimat majemuk. Walaupun istilah yang mereka gunakan berbeda-beda, namun inti pembahasannya sama. Berikut ini dipaparkan ringkasan pendapat beberapa ahli bahasa tentang kalimat majemuk dalam bahasa Indonesia.

1) Sutan Takdir Alisjahbana (STA) (1978)

Menurut STA, kalimat majemuk ialah susunan beberapa kalimat yang dalam hubungan kalimat-kalimat yang banyak itu amat rapat perhubungan isinya , sedangkan perhubungannya yang rapat itu ternyata pula pada cara menyusun kalimatkalimat itu, sehingga sekaliannya itu bersama-sama boleh dianggap sebuah kalimat baru. STA membedakan kalimat mejemuk atas dua jenis, yaitu kalimat mejemuk setara dan kalimat majemuk bertingkat. Kalimat majemuk setara ialah kalimat mejemuk yang terjadi dari beberapa kalimat yang setara. Ia menambahkan satu lagi jenis kalimat ke dalam kalimat mejemuk setara ini yaitu kalimat majemuk rapatan. Kalimat mejemuk rapatan adalah kalimat mejemuk yang hubungan antara kalimatkalimat di dalamnya lebih rapat lagi, yaitu mereka mempunyai bagian yang sama. Kalimat majemuk bertingkat adalah kalimat yang menjadi bagiannya itu ada kalimat yang menduduki sesuatu jabatan dalam kalimat lain. Kalimat yang menduduki suatu jabatan dalam kalimat lain itu dinamakan anak kalimat, sedangkan kalimat yang melingkungi anak kalimat itu dinamakan induk kalimat.

2) A.A. Fokker (1980)

Fokker tidak menggunakan istilah kalimat majemuk. Ia menggunakan istilah kalimat luas. Menurut Fokker, kalimat luas pada dasarnya diakibatkan oleh merapatkan dua (atau lebih) kalimat setara. Ia memberi catatan bahwa tidak semua kalimat luas diperoleh dengan merapatkan kalimat yang setara.

3) Samsuri, 1985.

Samsuri membagiproses pembentukan kalimat turunan dalam bahasa Indonesia atas lima macam, yakni (1) transformasi tunggal, (2) transformasi sematan, taranformasi rapatan, (4) transformasi fokus, dan (5) transformasi khusus. Transformasi tunggal bertolak dari sebuah kalimat dasar, sedangkan transformasi sematan dan rapatan bertolak dari dua kalimat dasar. Transformasi sematan dan 
rapatan sama dengan proses pemajemukan menurut ahli lain. Jadi, Samsuri tidak menggunakan istilah kalimat majemuk melainkan kalimat sematan dan rapatan.

Kalimat sematan adalah kalimat yang terjadi akibat sebuah kalimat dasar disematkan ke dalam kalimat dasar yang lain. Kalimat rapatan adalah kalimat yang merupakan hasil turunan dengan merapatkan kalimat yang satu ke kalimat yang lain.

4) Gorys Keraf, 1996 (cetakan ke XV)

Keraf membedakan pengertian kalimat majemuk berdasarkan proses pembentukannya. Pertama, kalimat mejemuk dipandang sebagai perluasan kalimat tunggal, kedua, kalimat majemuk dipandang sebagai hasil penggabungan dua atau lebih kalimat tunggal. Konsep yang pertama memandang kalimat majemuk adalah kalimat tunggal yang bagian-bagiannya diperluas sedemikan rupa, sehingga perluasan itu membentuk satu atau lebih pola kalimat yang baru di samping pola yang sudah ada. Sedangkan menurut konsep yang kedua, memandang kalimat majemuk sebagai penggabungan dari dua kalimat tunggal atau lebih, sehingga kalimat yang baru itu mengandung dua pola kalimat atau lebih.

Keraf membagi kalimat majemuk atas tiga macam.

(1) Kalimat mejemuk setara : bila hubungan antara kedua pola kalimat itu sederajat.

(2) Kalimat majemuk bertingkat : kalimat yang hubungan pola-polanya tidak sederajat. Bagian yang lebih tinggi kedudukannyanya disebut induk kalimat, sedangkan bagian yang lebih rendah kedudukannya disebut anak kalimat.

(3) Kalimat majemuk campuran: kalimat yang terdiri dari sebuah pola atasan dan sekurang-kurangnya dua pola bawahan, atau sekurang-kurangnya dua pola atasan dan satu atau lebih pola bawahan.

5) M. Ramlan (1987)

Ramlan tidak menggunakan istilah kalimat majemuk melainkan kalimat luas. Kalimat luas adalah kalimat yang terdiri dari dua klausa atau lebih. Kalimat luas dibedakan atas kalimat luas setara dan kalimat luas yang tidak setara. Dalam kalimat luas setara, klausa yang satu tidak merupakan bagian dari klausa lainnya; masing-masing berdiri sendiri-sendiri sebagai klausa yang setara, yaitu sebagai klausa inti semua. Dalam kalimat luas yang tidak setara klausa yang satu merupakan bagian dari klausa lainnya.

6) J.W.M. Verhaar (1999)

Kalimat majemuk adalah kalimat yang terdiri atas dua klausa atau lebih. Verhaar tidak menggolongkan kalimat majemuk secara aksplisit melainkan hanya menggolongkan berbagai jenis klausa yang membentuk kalimat majemuk. Klausa tersebut adalah:

(1) klausa mandiri dan klausa gabungan,

(2) klausa terkandung dan klausa berbatasan,

(3) klausa absolut dan klausa relasional,

(4) klausa lengkap dan klausa buntung,

(5) klausa koordinatif dan klausa subordinatif. 
7) Tata Bahasa Baku Bahasa Indonesia (1997)

Buku Tata Bahasa Baku yang disusun oleh Soenjono Dardjowidjojo, dkk. membahas berbagai hubungan yang terdapat antara satu klausa dengan klausa yang lain di dalam kalimat majemuk koordinatif dan subordinatif. Terdapat dua cara untuk menghubungkan klausa dalam sebuah kalimat majemuk, yaitu koordinasi dan subordinasi. Melalui koordinasi digabungkan dua klausa atau lebih yang masingmasing mempunyai kedudukan yang sama dalam struktur konstituen kalimat dengan menghasilkan satuan yang sama juga kedudukannya, sedangkan subordinasi menghubungkan dua klausa yang tidak mempunyai kedudukan yang sama dalam struktur konstituennya. Dengan kata lain, jika sebuah klausa berfungsi sebagai konstituen klausa lain, maka hubungan yang terdapat di antara kedua klausa itu disebut subordinasi.

Hubungan antarklausa dalam kalimat majemuk setara atau hubungan koordinatif meliputi:

(1) hubungan penjumlahan

(2) hubungan perlawanan

(3) hubungan pemilihan

Hubungan antarklausa dalam kalimat mejemuk bertingkat meliputi:

(1) hubungan waktu

(2) hubungan syarat

(3) hubungan tujuan

(4) hubungan konsesif

(5) hubungan pembandingan

(6) hubungan penyebaban

(7) hubungan akibat

(8) hubungan cara

(9) hubungan sangkalan

(10)hubungan kenyataan

(11)hubungan hasil

(12)hubungan penjelasan

(13)hubungan atributif

8) Rustiati (2013) dalam artikelnya yang berjudul "Kalimat Majemuk Kompleks" menyatakan bahwa kalimat majemuk kompleks adalah kalimat yang terdiri atas tiga klausa atau lebih, yaitu satu klausa utama dan sekurang-kurangnya dua klausa bawahan; atau sekurang-kurangnya dua klausa utama dan satu tau lebih klausa bawahan yang dihubungkan secara koordinatif dan subordinatif. Hubungan itu biasanya dibantu dengan berbagai konjungsi, baik yang biasa diapakai dalam kalimat majemuk setara maupun yang biasa dipakai dalam kalimat majemuk bertingkat. Selain itu, hubungan antarklausa dalam kalimat majemuk kompleks menimbulkan berbagai macam pola dan makna. Hasil penelitian Rustiati (2013) menunjukkan bahwa bahwa kalimat majemuk kompleks terdiri atas tujuh macam pola. 
9) Yulanda, dkk. (2015) dalam artikelnya yang berjudul "Kalimat Majemuk pada NovelRantau 1 Muara dan Implikasinya sebagai Bahan Ajar"menemukan penggunaan kalimat majemuk pada Novel Rantau I Muara terdapat tiga macam, yakni (1) kalimat majemuk setara, (2) kalimat majemuk bertingkat, dan (3) kalimat majemuk campuran.

Setelah mencermati semua pembahasan para ahli bahasa di atas, data kalimat yang mereka gunakan sebagai contoh kebanyakan kalimat dalam bahasa percakapan, kalimat kisahan dari cerita fiksi, dan sebagian besar kalimat rekaan atau data intuitif. Kalimat-kalimat yang dipakai sebagai contoh sebagian besar terdiri atas dua atau tiga klausa. Contoh-contoh tersebut tidak mencerminkan penggunaan bahasa yang alamiah. Nyaris tidak ada contoh kalimat yang diambil dari teks ilmiah yang pada umumnya panjang-panjang karena terdiri atas banyak klausa dan mengandung hubungan makna yang kompleks.

Penelitian ini memfokuskan diri pada penggunaan kalimat majemuk yang terdapat dalam teks ilmiah. Teks ilmiah yang dimaksudkan dalam penelitian ini adalah teks artikel ilmiah yang dimuat dalam jurnal ilmiah.Hal inilah yang membedakan pengkajian para ahli di atas dengan penelitian ini. Dengan demikian, penelitian ini dapat melengkapi teori kalimat majemuk bahasa Indonesia.

\section{METODE PENELITIAN}

\subsection{Sumber Data}

Sasaran penelitian ini adalah bahasa Indonesia yang mengenal ragam lisan dan tulisan. Data utama penelitian ini adalah kalimat yang digunakan dalam ragam tulis ilmiah. Pemilihan ragam tulis ilmiah sebagai sumber data utama didasarkan pada asumsi bahwa ragam bahasa tulis lebih menonjolkan bahasa Indonesia yang baku daripada bahasa lisan yang lebih banyak dipengaruhi faktor ekstralingual. Selain itu, kalimat majemuk sangat produktif dalam teks ilmiah. Teks ilmiah yang digunakan sebagai sumber data adalah artikel ilmiah yang terdapat dalam jurnal ilmiah.

\subsection{Metode dan Teknik Pengumpulan Data}

Data utama penelitian ini adalah bahasa tulis yang bersumber dari teks ilmiah, maka langkah-langkah penelitian adalah sebagai berikut:

1) teks dibaca dengan cermat agar dapat mengidentifikasi kalimat majemuk;

2) kalimat majemuk yang teridentifikasi dicatat dalam kartu data;

\subsection{Analisis Data}

Data yang telah terkumpul dan teridentifikasi dianalisis dengan prosedur sebagai berikut.

1) Kalimat majemuk yang telah teridentifikasi diklasifikasikan berdasarkan persamaan struktur.

2) Masing-masing kalimat majemuk tersebut dianalisis strukturnya untuk merekonstruksi klausa-klausa yang membentuk kalimat tersebut.

3) Langkah berikutnya adalah merumuskan kaidah-kaidah pembentukan kalimat majemuk sesuai dengan tipe masing-masing. 


\section{HASIL PENELITIAN DAN PEMBAHASAN}

\subsection{Struktur Kalimat Majemuk Bahasa Indonesia dalam Teks Ilmiah}

\subsubsection{Struktur Kalimat Majemuk Koordinatif}

Hubungan koordinasi merupakan hubungan antara dua klausa atau lebih yang masingmasing mempunyai hubungan yang setara dalam struktur susunan kalimat. Hasil penelitian menunjukkan bahwa kalimat majemuk koordinatif dalam teks ilmiah ada yang terdiri atas dua klausa, ada pula yang terdiri atas tiga klausa.

1) Kalimat Majemuk Koordinatif yang terdiri atas Dua Klausa

Hasil penelitian menemukan pada umumnya struktur klausa dalam kalimat majemuk koordinatif yang terdiri atas dua klausa berpola S P Komp + S P Komp.

\section{Contoh:}

(1) Sementara itu, teks-teks dalam kelompok genre sastra dikategorikan ke dalam genre cerita, sedangkan teks-teks genre nonsastra dikelompokkan ke dalam genre faktual dan genre tanggapan. (SD 1)

Kalimat di atas diawali dengan pemarkah anafora sementara itu yang menunjukkan bahwa kalimat tersebut merupakan kalimat yang menjelaskan kalimat sebelumnya.Kalimat di atas terdiri atas dua klausa yang kedudukannya setara sehingga disebut kalimat majemuk koordinatif/setara. Hubungan setara tersebut dimarkahi konjungsi sedangkan.

Kalimat di atas terdiri atas dua klausa, yaitu (1) teks-teks dalam kelompok genre sastra dikategorikan ke dalam genre, cerita, (2) teks-teks genre nonsastra dikelompokkan ke dalam genre faktual dan genre tanggapan.

Pola klausa di atas sebagai berikut:

\section{Kl 1: S P Komp}

teks-teks dalam kelompok genre sastra dikategorikan ke dalam genre cerita $S$ $\boldsymbol{P}$ Komp

$\mathrm{K} 12$ :S P Komp

teks-teks genre nonsastra dikelompokkan ke dalam genre faktual dan genre tanggapan

$$
S \quad P \quad \text { Komp }
$$

Contoh lain, kalimat (2) berikut.

(2) Selain itu, karena teks digunakan untuk pernyataan suatu kegiatan sosial dengan struktur berpikir yang lengkap, maka setiap teks memiliki struktur tersendiri dengan jenis yang berbedapula. (SD 1)

Kalimat (2) di atas diawali pemarkah anafora selain itu yang menunjukkan kalimat tersebut merupakan kalimat yang menjelaskan kalimat sebelumnya.Kalimat di atas terdiri atas dua klausa yang 
kedudukannya setara sehingga dikelompokkan ke dalam kalimat majemuk koordinatif. Hubungan setara tersebut dimarkahi konjungsi sedangkan.

Kalimat (2) di atas terdiri atas dua klausa, yaitu (1) teks digunakan untuk pernyataan suatu kegiatan sosial dengan struktur berpikir yang lengkap, (2) setiap teks memiliki struktur tersendiri dengan jenis yang berbedapula. Pola klausa di atas sebagai berikut:

Kl 1: S P Komp

Teks digunakan untuk pernyataan suatu kegiatan sosial dengan struktur berpikir

$S \quad P$

Komp

yang lengkap

K1 2 :S P Komp

setiap teks memiliki struktur tersendiri dengan jenis yang berbedapula

$\begin{array}{lll}S & \boldsymbol{P}\end{array}$

2) Kalimat Majemuk Koordinatif yang terdiri atas Tiga Klausa

Pada umumnya struktur kalimat majemuk koordinatif yang terdiri atas tiga klausa berpola sama dengan kalimat majemuk koordinatif yang terdiri atas dua klausa. Ada klausa yang lengkap dengan unsur keterangan (Ket). Sebagai contoh, kalimat berikut berpola S P Komp Ket + S P Komp + S P Komp Ket

(1) Dalam konteks Kurikulum 2013, Menteri Pendidikan dan Kebudayaan republik Indonesia, Prof. Dr. Ir. H. Muhammad Nuh, D.E.A.

menempatkan posisi bahasa Indonesia sebagai penghela ilmu pengetahuan, bahasa Indonesia tidak hanya menjadi sarana untuk mengomunikasikan ilmu pengetahuan tetapi juga sebagai sarana untuk mengembangkan dan mentransmisikan ilmu pengetahuan itu sendiri dari generasi ke generasi. (SD 1)

Kalimat di atas terdiri atas 3 klausa, yaitu (1) Menteri Pendidikan dan Kebudayaan republik Indonesia, Prof. Dr. Ir. H. Muhammad Nuh, D.E.A.menempatkan posisi bahasa Indonesia sebagai penghela ilmu pengetahuan, (2) bahasa Indonesia tidak hanya menjadi sarana untuk mengomunikasikan ilmu pengetahuan, (3) sebagai sarana untuk mengembangkan dan mentransmisikan ilmu pengetahuan itu sendiri dari generasi ke generasi.

Kalimat di atas tergolong kalimat majemuk koordinatif karena klausa yang terdapat dalam kalimat tersebut mempunyai kedudukan yang sama. Hubungan koordinatif ketiga klausa tersebut ditandai tanda koma antara kalusa 1 dan kalusa 2 serta pemarkah ... tidak hanya ... pada klausa kedua dan ... tetapi juga ... dalam klausa 3.

Pola ketiga klausa di atas sebagai berikut: 
Kl 1berpola :S P Komp Ket

Menteri Pendidikan dan Kebudayaan republik Indonesia, Prof. Dr. Ir. H. Muhammad Nuh, D.E.A. menempatkanposisi bahasa Indonesia sebagai penghela

$$
\boldsymbol{S} \quad \boldsymbol{P} \quad \frac{\text { ilmu pengetahuan }}{\operatorname{Komp}}
$$

K1 2 berpola :S P Komp

bahasa Indonesia tidak hanya menjadi saranauntuk mengomunikasikan

$\boldsymbol{S} \boldsymbol{P}$

ilmu pengetahuan

Komp

Kl 3 berpola :S P Komp Ket

sebagai saranauntuk mengembangkan dan mentransmisikan

$\boldsymbol{S} \boldsymbol{P}$

ilmu pengetahuan itu sendiridari generasi ke generasi

Komp Ket

Berikut adalah contoh lain kalimat majemuk setara yang terdidi atas tiga klausa.

(1) Register menyangkut pesan apa yang akan disampaikan (medan/field), kepada siapa pesan itu ditujukan (pelibat/tenor), dan dalam format bahasayang bagaimanakah pesan itu disampaikan (sarana/mode). (SD 1)

(2) Danfaktadilapanganpadasaatpenelitianbeberapapesertadidikbelumma mpumenggunakankecerdasanemosionalnyadenganbaik,karenamasih adabeberapapesertadidikyangmengganggutemannyapadasaatmengi siangket meski peneliti sudah berusaha untukmemperingati. (SD 2)

\subsubsection{Struktur Kalimat Majemuk Subordinatif dalam Teks Ilmiah}

Kalimat majemuk bertingkat adalah kalimat yang mengandung satu kalimat dasar yang merupakan inti (utama) dan satu atau beberapa kalimat dasar yang berfungsi sebagai pengisi salah satu unsur kalimat inti itu, misalnya keterangan, subjek, atau predikat. Di antara kedua unsur itu digunakan konjungsi (Sugono, 2009: 172).

Struktur kalimat majemuk subordinatif dalam penelitian ini terdapat beberapa tipe sesuai dengan jumlah klausa yang terdapat di dalamnya.

1) Struktur Kalimat Majemuk Subordinatif yang Terdiri atas Dua Klausa

Struktur kalimat mejmuk subordinatif ini terdiri atas beberapa tipe.

Tipe 1:berpola S (s P Komp) + P Komp Ket.

Contoh:

(1) Pembelajaran berbasis teks dirumuskan sebagai formula efektif untuk mensejajarkan pelaksanaan pendekatan ilmiah (pendekatan saintifik) 
sebagai "teman sejati"dalam pelaksanaan Kurikulum2013.(SD 1)

Kalimat di atas terdiri atas dua klausa.

KI 1:pembelajaran berbasis teks dirumuskan sebagai formula efektif

\section{$\underline{S}$}

(S

$\mathbf{P} \quad$ Komp)

KI 2:mensejajarkanpelaksanaan pendekatan ilmiah (pendekatan saintifik)

P Komp.

sebagai "teman sejati"dalampelaksanaanKurikulum2013

\section{Ket}

Klausa pertama merupakan klausa inti sedangkan klausa kedua merupakan atribut.

KI 1 berpola: $\quad \mathbf{S}$ (S $\mathbf{P}$ Komp)

Klausa pertama ini berfungsi sebagai subjek (S) dalam kalimat di atas.

KI 2 berpola:P Komp Ket berfungsisebagai predikat $(P)$ komplemen (Komp.), dan Keterangan (Ket) dalam kalimat di atas. Jadi, klausa pertama berfungsi sebagai subjek dari klausa kedua.

Berikut ini contoh lain kalimat yang memiliki pola yang sama dengan kalimat di atas.

(1) Perilaku-perilaku negatifyang masih dilakukan peserta didik dikelas dipengaruhi oleh beberapa factor seperti lingkungan sosial dan lingkungan keluarga. (SD 2)

(2) Pesertadidik mampu berkomunikasi dengan baik jika didukung dengan emosi yang baik (Endriani, 2017). (SD 2)

(3) Pembelajaran Bahasa Indonesia untuk multi jenjang selalu bergerak dinamis mengikuti perkembangan manusia sebagai pelaku dan pemilik bahasa itu sendiri. (SD 1)

Tipe 2: berpola S P Komp + $\operatorname{Ket}_{(\mathbf{P} \text { Komp })}$

Contoh:

(1) Emosi merupakan bentuk yang kompleks dari organisme, yang melibatkan perubahan fisik dari karakter yangluas dalam bernafas, denyutnadi, produksikelenjar, dansebagainya. (SD 2)

Kalimat (1) di atas terdiri atas dua klausa. 
KI 1 :emosimerupakanbentukyangkompleks dari organisme

S $P$ Komp

KI 2 :yangmelibatkanperubahanfisikdarikarakteryangluasdalambernafas, denyutnadi,produksikelenjar, dansebagainya

\section{$\underline{\text { Ket }}$}

$(\boldsymbol{P}$

Komp)

Hubungan antarkedua klausa tersebut bersifat subordinatif, klausa pertama merupakan inti sedangkan klausa kedua merupakan atribut.

$\mathrm{KI} 1$ berpola :S $\mathbf{P}$ Komp

$\mathrm{KI} 1$ berfungsi sebagai subjek (S), predikat $(\mathrm{P})$, komplemen (Komp) kalimat di atas.

$\mathrm{KI} 2$ berpola: $\quad \underline{\text { Ket }}$ ( $\mathrm{P}$ Komp)

$\mathrm{KI} 2$ berfungsi sebagai keterangan (Ket) dalam kalimat tersebut. Jadi, klausa kedua menduduki fungsi keterangan (Ket) dalam kalimat (1) di atas.

Berikut ini adalah contoh lain kalimat yang memiliki pola yang sama dengan kalimat (1) dan kalimat (2) di atas.

(1) Selaras dengan hal tersebut, maka teks didefinisikan sebagai satuan bahasa yang digunakan sebagai ungkapan suatu kegiatan sosial baik secara lisan maupun tulis dengan struktur berpikir yang lengkap (Mahsun, 2014:1). (SD 1)

(2) Tentu saja, warna pembelajaran Bahasa Indonesia menyesuaikan dengan titipan konsep pembelajaran yang ditawarkan setiap kurikulum. (SD 1)

(3) Selanjutnya, setiap subgenre tersebut memiliki tujuan sosial tersendiri yang masing-masing mengejewantahkan diri dalam berbagai jenis teks. (SD 1)

2) Struktur Kalimat Majemuk Subordinatif yang Terdiri atas Tiga Klausa

Struktur kalimat mejmuk subordinatif ini terdiri atas beberapa tipe.

Tipe 1 : berpola S P Komp $\left(\mathbf{P}\right.$ O) $+\operatorname{Ket}_{(\mathbf{P} \text { Komp) }}$ Contoh:

(1) Selain itu, pembelajaran Bahasa Indonesia berbasis teks dimaknai sebagai pembelajaran yang mengantarkan peserta didik untuk dapat berpikir sistematis, terkontrol, empiris, dan kritis. (SD 1)

Pola kalimat (1) di atas sebagai berikut:

Kalimat (1) di atas terdiri atas tiga klausa.

$\mathrm{KI} 1$ berpola : $\mathrm{S}+\mathrm{P}+\mathrm{Komp}$ 
selain itu pembelajaran Bahasa Indonesia berbasis teksdimaknai

\section{$s$}

$P$

sebagai pembelajaran

\section{Komp}

$\mathrm{KI} 2$ berpola : $\mathrm{P} \mathrm{O}$

\section{mengantarkanpeserta didik}

$\boldsymbol{P}$

$\mathrm{KI} 3$ berpola : P Komp

untukdapat berpikirsistematis, terkontrol, empiris, dankritis

$P$

Komp

Hubungan antara ketiga klausa di atas adalah hubungan subordinatif.Klausa pertama adalah klausa inti, sedangkan klausa kedua dan ketiga adalah atribut. Klausa kedua menduduki fungsi sebagai komplemen (Komp). Struktur lahir (surface structure) klausa kedua berpola P S, tetapi struktur batinnya (deep structure) berpola $\mathrm{S}$ $\mathrm{P} \quad$ O. Subjek klausa kedua adalah komplemen klausa pertama ...pembelajaran ... atau dengan kata lain komplemen klausa pertama menjadi subjek klausa kedua. Oleh sebab itu pola klausa kedua digambarkan:

Komp ( S P O)

Klausa ketiga menduduki fungsi sebagai Keterangan (Ket) kalimat. Klausa tersebut berpola P + Komp sehingga digambarkan berpola:Ket (P Komp).

Contoh lain yang mirip dengan kalimat di atasa adalah kalimat (2) berikut ini.

(2) Dengan demikian, genre dapat didefinisikan sebagai jenis teks yang berfungsi menjadi rujukan agar suatu teks dapat dibuat lebih efektif, baik dari segi ketepatan tujuannya (tujuan sosial), maupun ketepatan pemilihan dan penyusun elemen teks, dan ketepatan dalam penggunaan unsur tata bahasanya. (SD 1)

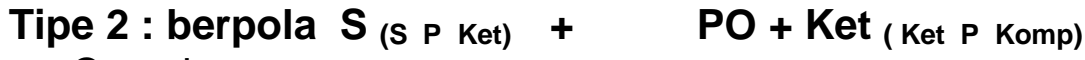

Contoh :

(1) Capaian pembelajaran Bahasa Indonesia pada setiap multijenjang mulai pendidikan dasar sampai dengan menengah berorientasi secara konsisten untukmeningkatkan keterampilan berbahasa Indonesia peserta didik,baik secara lisan maupun tulis dengan menggunakan bahasa Indonesia yang baik dan benar. (SD 1)

Kalimat di atas terdiri atas tiga klausa. 
KI 1 : berpola $\quad \mathbf{S}_{\text {(S P Ket) }}$

Capaian pembelajaran Bahasa Indonesia pada setiap multijenjang mulai pendidikan dasar sampai dengan menengah berorientasisecara konsisten<smiles>[Mg]=[SbH]</smiles>

$\mathrm{KI}$ 2: berpola $\mathbf{P} \mathbf{O}$

untukmeningkatkanketerampilan

berbahasalndonesiapesertadidik,<smiles>[2H]P</smiles>

$\mathrm{KI} 3$ :berpola $\mathbf{K e t}_{(\mathbf{S}+\mathbf{P}+\mathrm{Ket})}$

Baik secara lisan maupun tulis dengan mengqunakan bahasa Indonesia

benar.

yang baik dan

\section{$\underline{\text { Ket }}$}

$\begin{array}{lll}\text { Ket } & P & \text { Komp) }\end{array}$

Hubungan antara ketiga klausa di atas bersifat subordinatif.Klausa pertama merupakan inti, sedangkan klausa kedua dan ketiga merupakan atribut.Subjek klausa kedua adalah klausa pertama. Itulah sebabnya klausa pertama berpola $\mathbf{S}_{(\mathbf{S}} \mathbf{P}$ Ket) atau $\mathbf{S}(\mathbf{S}+\mathbf{P}+\mathbf{0})$.Klausa kedua menduduki fungsi predikat $(\mathrm{P})$ dan objek $(\mathrm{O})$. Klausa ketiga menduduki fungsi keterangan kalimat.

Tipe 3 berpola: $\mathbf{S}$ (S P Komp) + P Komp + P Komp

Contoh:

(1) Matematikamerupakanilmuuniversalyangmendasariperkembanga nilmupengetahuandanteknologimodern,memajukandayapikirsertaa nalisamanusia. (SD 2)

Kalimat (1) di atas terdiri atas tiga klausa.

Kl 1: berpola $\mathbf{S} \quad$ (S + P + Komp)

Matematika merupakan ilmu universal

\section{$\underline{S}$}

G $P$

Kond

$\mathrm{KI} 2$ : berpola $\mathbf{P}$ Komp

yangmendasariperkembanganilmupengetahuandanteknologim odern,

$\boldsymbol{P}$

K1 2 : berpola : P Komp

Komp

memajukandaya pikir serta analisa manusia.

$\boldsymbol{P}$ Komp


Hubungan antarklausa dalam kalimat di atas adalah hubungan subordinatif.Klausa pertama merupakan klausa inti, sedangkan klausa kedua dan ketiga adalah atribut.Klausa pertama berfungsi sebagai subjek kalaimat, sedangkan klausa kedua menduduki fungsi predikat (P) dan komplemen (Komp). Demikian juga klausa ketiga menduduki fungsi predika ( $\mathrm{P}$ dan komplemen (Komp). Hubungan antara klausa kedua dan klausa ketiga bersifat koordinatif.

\subsubsection{Struktur Kalimat Majemuk Kompleks dalam Teks Ilmiah}

Chaer (2003: 246) mengemukakan bahwa kalimat majemuk kompleks adalah kalimat yang terdiri dari tiga klausa atau lebih, di mana ada yang dihubungkan secara koordinatif dan ada pula yang dihubungkan secara subordinatif. Keraf menggunakan istilah kalimat majemuk campuran untuk kalimat majemuk kompleks adalah kalimat yang terdiri dari sebuah pola atasan dan sekurang-kurangnya dua pola bawahan; atau sekurang-kurangnya dua pola atasan dan satu aatau lebih pola bawahan (1978: 190).

Menurut kedua ahli di atas patokan utama kalimat majemuk kompleks adalah kalimat tersebut terdiri atas tiga klausa. Tetapi menurut peneliti penentuan utama kalimat majemuk kompleks adalah kompleksitas pola hubungan antarklausa di dalam kalimat tersebut. Jadi, kalimat majemuk kompleks adalah kalimat majemuk yang pola hubungan antarklausa di dalamnya bersifat kompleks yang merupakan campuran antara hubungan koordinatif dan subordinatif.

Hasil penelitian menunjukkan, struktur kalimat majemuk kompleks dalam teks ilmiah memiliki beberapa tipe sebagai berikut.

Tipe 1: berpola $S_{(S \text { P Komp })}+P O+P O+P$ Komp

Contoh:

(1) Kemampuan komunikasi matematis meliputi beberapa indikator yaitu menghubungkan benda nyata, gambar, tabel, dan diagram kedalam ide matematika; menjelaskan ide, situasi dan relasi matematika secara tulisan dengan benda nyata, gambar, grafik, dan aljabar; danmenyatakan peristiwa sehari-hari dalam bahasa atau simbol matematis (Syarifah, etal.,2017). (SD 2)

Kalimat di atas terdiri atas empat klausa.

KI 1: berpola $\boldsymbol{P}_{(S} \quad \boldsymbol{P} \quad$ Komp) kemampuan komunikasi matematis meliputi beberapa indikator yaitu

\section{$\underline{P}$}

(S

$\mathrm{KI}$ 2: berpola $\mathbf{P} \mathbf{O}$

$P \quad$ Komp)

menghubungkan benda nyata, gambar, tabel, dan diagram ke dalam

$\underline{\text { ide }}$

$$
\boldsymbol{P} \quad \frac{\text { matematika; }}{\boldsymbol{O}}
$$

$\mathrm{KI} 3$ : berpola $\mathbf{P} \mathbf{O}$

menjelaskan ide, situasidan relasi matematika secaratulisan dengan benda 


\section{$\boldsymbol{P}$}

nyata, gambar, grafik, danaljabar;

$\mathrm{KI} 4$ : berpola $\mathbf{P}$ Komp

Dan menyatakan peristiwa sehari-hari dalam bahasa atau simbol matematis

$\mathbf{P}$

Komp

Hubungan antarklausa dalam kalimat di atas bersifat subordinatif. Klausa pertama adalah klausa inti dan sekaligus berfungsi sebagai subjek kalimat.Klausa kedua, ketiga, dan keempat merupakan atribut.Hubungan antara klausa kedua, ketiga, dan keempat bersifat koordinatif karena kedudukannya setara. Hubungan antarklausa dalam kalimat tersebut bersifat kompleks karena hubungan antara klausa pertama dengan klausa lain bersifat subordinatif, sedangkan hubungan antarklausa atribut bersifat koordinatif.

Tipe 2 : berpola Ket + S P O Ket + P O Ket + P O Ket P $_{(\mathbf{P})}+$ P Komp + P Komp

Contoh :

(1) Berdasarkan hasil wawancara dengan salah satu guru matematika di SMP Negeri 24 Mataram, bahwa tingkah laku peserta didik masih ada yang mengganggu temandikelas, membuat keributan di kelas, tidakmemperhatikan guru pada saat guru memberikan materi, berbicara dengan teman sebangkunya, dan menghormati guru yang mereka anggap senior namun berbeda perlakuan terhadap guru PPL. (SD 2)

Kalimat di atas terdiri atas tujuh klausa.

KI 1 : berpola : Ket + S P O Ket

Berdasarkan hasil wawancara dengansalahsatugurumatematikadiSMPNegeri 24Mataram, Ket

bahwatingkahlakupesertadidikmasih ada yang mengqangqutemandi kelas

S

$\mathbf{P}$

0

Ket

$\mathrm{KI} 2$ : berpola P O Ket

membuatkeributandikelas

$\begin{array}{lll}P & 0 & K e t\end{array}$

KI 3: berpola P O Ket(P o)

tidakmemperhatikangurupada saatqurumemberikanmateri

$\begin{array}{lllll}P & O & K e t & \text { (s } & P\end{array}$

o)

$\mathrm{KI} 4$ : berpola P Komp

berbicaradengantemansebangkunya 


\section{$\boldsymbol{P}$}

Komp

$\mathrm{KI} 5$ : berpola P Komp

danmenghormatiguru yangmerekaanggapsenior

$P$

0

$\mathrm{KI} 6$ : berpola P Komp

namunberbedaperlakuanterhadapguruPPL

$$
P \quad \text { Komp }
$$

Hubungan antarklausa dalam kalimat di atas bersifat koordinatif. Yang menarik adalah pola klausa tiga yang memiliki klausa atribut yang berfungsi sebagai keterangan klausa tersebut.

Tipe 3 : berpola S P Komp + Ket (P Komp + Ket (P Komp) $)+$ S P Komp ( P O + P O + P $\mathbf{O}+\mathbf{P} \mathbf{O}+\mathbf{P} \mathbf{O})$

Contoh:

(1) Peserta didik yang mempunyai kecerdasan emosional akan lebih bisa mengendalikan dirinyasaat menghadapi masalah dalam belajar khususnya dalam belajar matematika, karena kecerdasan emosional terdiri dari indikator-indikator di antaranya: mengenali emosi diri, mengelola emosidiri sendiri, memotivasi diri sendiri, mengenali emosi orang lain, dan membina hubungan dengan orang lain.(SD 2)

Kalimat di atas terdiri atas tiga klausa utama. Klausa kedua memilili dua anak klausa atau subklausa; subklausa kedua memiliki satu subklausa pula. Klausa ketiga memiliki lima subklausa. Pola klausa kalimat di atas sebagai berikut.

$\mathrm{Kl} 1$ : berpola : S P Komp

Pesertadidikyangmempunyaikecerdasanemosional

\section{$S$}

akanlebihbisamengendalikandirinya

$\mathrm{KI} 2$ : berpola Ket (P Komp + Ket (P Komp))

\section{Komp}

saatmenghadapimasalahdalambelajarkhususnyadalambelajarmate matika
Ket(
Komp + Ket (
P Komp)

Kl 3 : berpola S P Komp ( P Komp + P Komp + P Komp + P Komp + P Komp)

karenakecerdasanemosionalterdiridariindikator-

indikatordiantaranya:

$s$

p Komp Ket

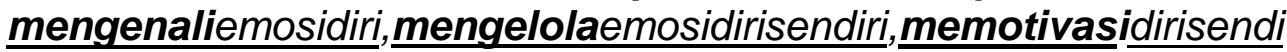

$\underline{r i}$,

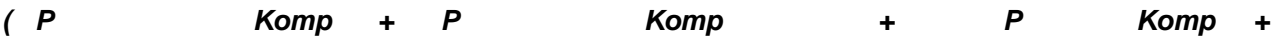


$\underline{\text { mengenaliemosioranglain, danmembinahubungandenganoranglain }}$

$P$ Komp $+P$

Komp )

Hubungan atarklausa utama dalam kalimat di atas bersifat subordinatif. Klausa pertama adalah klausa inti, sedangkan klausa kedua dan ketiga merupakan klausa penjelas. Klausa kedua memiliki dua subklausa.Hubungan antara dua subklausa tersebut bersifat subordinatif. Klausa ketiga memiliki lima subklausa. Hubungan antara kelima klausa tersebut bersifat koordinatif.

Kalimat berikut ini juga memiliki pola yang hampir sama.

(1)

Nilai kemampuan komunikasi matematis biasanya hanya ditunjukkan dalam bentuk angka yang tinggi rendahnya menunjukkan seberapa jauh peserta didik dapat menghubungkan benda nyata, gambar, tabel, dan diagram ke dalam ide matematika; menjelaskan ide, situasi, dan relasi matematika secara tulisan dengan benda nyata, gambar, grafik, dan aljabar; dan menyatakan peristiwa sehari-hari dalam bahasa atau simbol matematis. (SD 2)

(2) Peserta didik yang mampu mengendalikan emosi pada saat pembelajaran matematika seperti mengikuti pembelajaran matematika yang tertib namun tida kmencermati pembelajaran matematika, sehingga kecerdasan emosional peserta didik tidak memiliki hubungan secara signifikan dengan kemampuan komunikasi matematis. (SD 2)

Tipe 4 : berpola : S P Komp + Ket S P + S P Komp + P Komp + P Komp Contoh:

(1) Hakikat dilaksanakannya pembelajaran Bahasa Indonesia berbasis teks itu sendiri adalah pertama: melalui teks, kemampuan berpikir siswa dapat dikembangkan; kedua: materi pembelajaran berupa teks lebih relevan dengan karakteristik Kurikulum 2013 yang menetapkan capaian kompetensi siswa yang mencakupi ketiga ranah pendidikan: sikap, pengetahuan, dan keterampilan. (SD 1)

Kalimat di atas terdiri atas terdiri atas lima klausa, dengan pola klausa sebagai berikut.

$\mathrm{KI} 1$ : berpola S P Komp

Hakikat dilaksanakannya pembelajaran Bahasa Indonesia $\underline{\text { berbasis teks itu }}$

\section{Sendiri}

\section{S $P$ Komp}

$\mathrm{KI} 2$ : berpola Ket $\mathbf{S} \mathbf{P}$

melalui teks, kemampuan berpikir siswa dapat dikembangkan

Ket 
KI 3 : berpola S $\mathbf{P}$ Komp

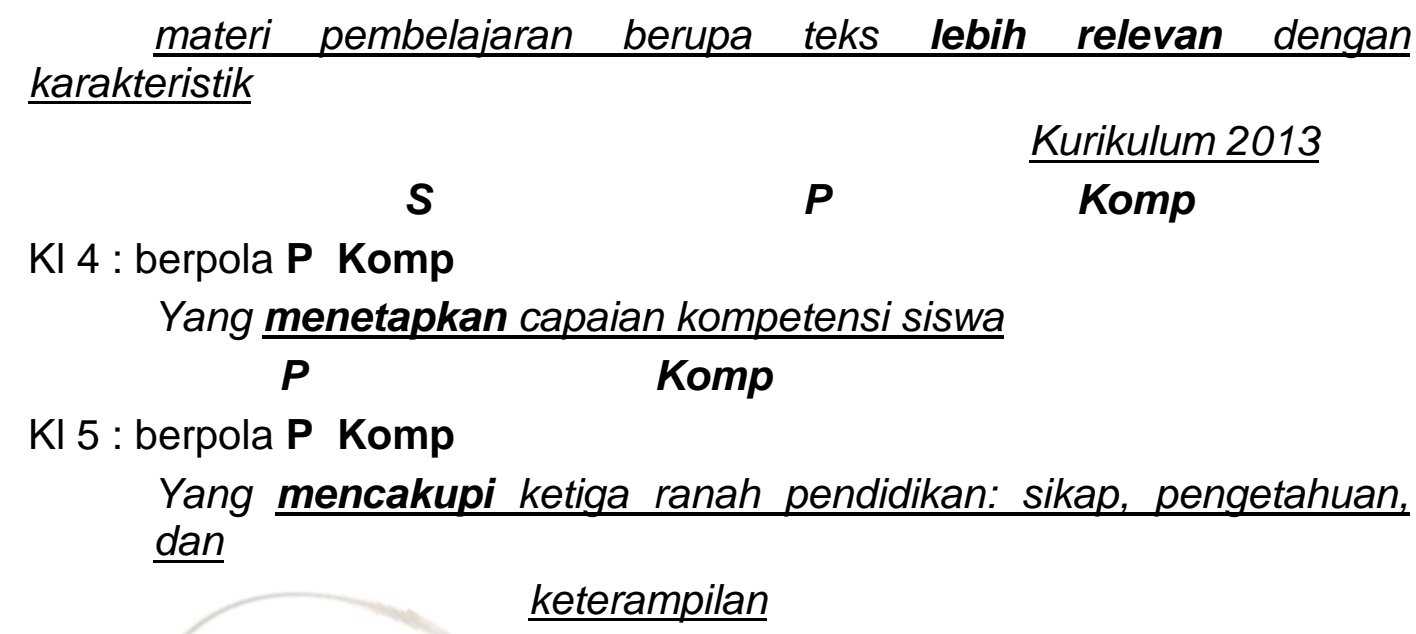

Hubungan antarklausa dalama kalimat di atas adalah hubungan subordinatif. Klausa pertama merupakan klausa inti, sedangkan klausa kedua sampai klausa kelima merupakan atribut atau klausa penjelas. Hubungan antara klausa kedua dan ketiga bersifat koordinatif. Sedangkan hubungan antara klausa ketiga dengan klausa keempat dan kelima bersifat subordinatif.Klausa ketiga merupakan inti, sedangkan klausa keempat dan kelima merupakan atribut klausa ketiga.

Tipe 5 : berpola : P P O + P Komp + P Komp

Contoh :

(1) Untuk memahami dan menguasai informasi dan teknologi yang berkembang pesat khususnya peserta didik maka diperlukan penguasaan pembelajaran matematika sejak dini. (SD 2)

Pola kalimat di atas adalah:

Untuk memahami dan menguasai informasi dan teknologi

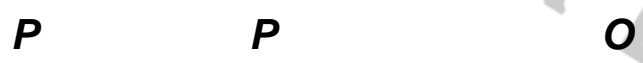

Yang berkembang pesat khususnya peserta didik

$$
\boldsymbol{P} \quad \text { Komp }
$$

Maka diperlukan penguasaan pembelajaran matematika sejak dini.

\section{$\boldsymbol{P} \quad$ Komp}

Struktur lahir kalimat di atas tampaknya terdiri atas tiga klausa. Namun, setelah direkostruksi ternyata kalimat tersebut terdiri atas empat klausa karena klausa pertama merupakan gabungan dua klausa.Hal itu tampak dalam predikat serial (serial verb). Pola klausa tersebut sebagai berikut. 
$\mathrm{KI} 1$ : berpola $\mathbf{P} \mathbf{O}$

untukmemahami informasi dan teknologi

$\boldsymbol{P}$

0

$\mathrm{KI} 2$ : berpola $\mathbf{P} \mathbf{O}$

untukmenguasai informasi dan teknologi

$\boldsymbol{P}$

0

$\mathrm{KI} 3$ : berpola $\mathbf{P}$ Komp

yangberkembangpesatkhususnyapesertadidik

\section{P Komp}

$\mathrm{KI} 4$ : berpolaP Komp

makadiperlukanpenguasaanpembelajaran

matematikasejakdini.

\section{$P \quad$ Komp}

Hubungan antarklausa dalam kalimat tersebut cukup kompleks.Hubungan antara klausa pertama dan kedua yang digabung menjadi satu bersifat koordinatif, namun hubungan antara kedua klausa tersebut dengan klausa ketiga dan klausa keempat bersifat subordinatif.

Struktur yang mirip dengan struktur kalimat di atas, yakni berpredikat ganda (serial verb) terdapat dalam kalimat berikut ini.

(1) Peserta didik masih ada yang menanyakan cara menyelesaikan soaltersebut meski peneliti sudah memberi tahu untuk mengerjakan sesuai dengan kemampuan, ada peserta didik yang mengatakan sudah lupa dengan materi yang berkaitan dengan tes, dan ada peserta didik yang mengatakan bahwa matematika sulit. (SD 2)

Tipe 6 : berpola : S (P o + P O + P O+P O+P o $)+$ P O + P O (s + P Komp $)$ Contoh:

(1) Meskipun peserta didik dapat mengenali emosi diri, mengelola emosi diri sendiri, memotivasi diri sendiri, mengenali emosi orang lain, serta mampu menjaga hubungan baik dengan orang lain jika tidak memiliki pengetahuan prasyarat yang baik tentu tidak dapa tmenjawab soal matematika khususnya soal matematika yang disajikan sesuai dengan indikator kemampuan komunikasi matematis. (SD 2)

Kalimat di atas terdiri atas tiga klausa utama. Klausa pertama memiliki lima subklausa. Klausa ketiga memiliki satu subklausa.Pola klausa tersebut sebagai berikut. 
$\mathrm{KI} 1$ : berpola S (P Komp + P Komp + P Komp + P o + P o)

Meskipun pesertadidik dapat mengenali emosi diri, mengelola emosi diri

$$
S \quad \text { Komp } \quad+P \quad \text { Komp }
$$

Memotivasi diri sendiri, mengenali emosi orang lain,

$$
P \quad \text { Komp }+\quad P \quad O \quad+
$$

Serta mampu menjaga hubungan baik dengan orang lain

$$
P \quad 0 \text { ) }
$$

$\mathrm{KI} 2$ : berpola $\mathbf{P} \mathbf{O}$

Jika tidak memiliki pengetahuan prasyarat yang baik

$$
\mathbf{P}
$$

\section{0}

$\mathrm{KI} 3$ : berpola $\mathbf{P} \mathbf{O}(\mathrm{s}+\mathrm{P}$ Komp)

Tentu tidak dapat menjawab soal matematika khususnya soal matematika

Yang disajikan sesuai dengan indikator kemampuan komunikasi $\underline{\text { matematis }}$

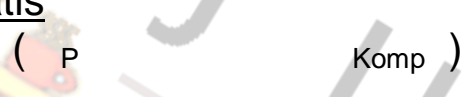

Hubungan antara klausa utama dalam klausa di atas bersifat subordinatif. Klausa pertama merupakan klausa inti, sedangkan klausa kedua dan ketiga merupakan klausa penjelas. Klausa pertama memiliki lima subklausa yang masing-masing berfungsi sebagai predikat dan objek/komplemen. Hubungan antara klausa kedua dan ketiga bersifat koordinatif.Klausa ketiga memiliki satu subklausa. Baik klausa pertama, maupun klausa kedua, dan ketiga memiliki subjek yang sama, yaitu ...peserta didik....

\section{Tipe 7 berpola :S $(\mathrm{P}$ O + P O + P + P O + P) + S P Komp}

Contoh:

(1) Kemampuan emosiseperti mengatasi suatu konflik, mengendalikan marah, berkonsentrasi, mengarahkan diri, berempati, dan keterampilan sosialcenderung tidak dilakukan penilaian (Putri,2107). (SD 2)

Kalimat di atas terdiri atas dua klausa utama dan lima klausa bawahan yang merupakan keterangan subjek klausa pertama. Kalimat di atas dapat direkonstruksi sebagai berikut.

Klausa utama dalam kalimat di atas adalah "kemampuan emosi dan keterampilan sosial cenderung tidak dilakukan penilaian" Klausa tersebutterdiri atas dua klausa, yakni (1) "kemampuan emosi tidak dilakukan penilaian", dan (2) keterampilan sosial tidak dilakukan penilaian." Klausa pertama memiliki lima klausa bawahan yang merupakan penjelas subjek klausa pertama. Jika direkonstruksi, maka wujud klausa pertama adalah 
"Kemampuan emosi seperti mengatasi suatu konflik, mengendalikan marah, berkonsentrasi, mengarahkan diri, berempati, tidak dilakukan penilaian".

\subsection{Hubungan Antarklausa dalam Kalimat Majemuk Bahasa Indonesia dalam Teks Ilmiah}

\subsubsection{Hubungan Antarklausa dalam Kalimat Majemuk Koordinatif}

Hasil penelitian menunjukkan hubungan antarklausa dalam kalimat majemuk koordinatif dalam teks ilmiah meliputi hubungan perlawanan, hubungan pemilihan, dan hubungan aditif/penambahan.

1) Hubungan perlawanan dimarkahi konjungsi:sedangkan, karena ... meski

Contoh:

(1) Sementara itu, teks-teks dalam kelompok genre sastra dikategorikan ke dalam genre cerita, sedangkan teks-teks genre nonsastra dikelompokkan ke dalam genre faktual dan genre tanggapan. (SD 1)

(2) Dan fakta di lapangan pada saat penelitian beberapa peserta didik belum mampu menggunakan kecerdasan emosionalnya dengan baik, karena masih ada beberapa peserta didik yang mengganggu temannya pada saat mengisi angket meski peneliti sudah berusaha untuk memperingati. (SD 2)

2) Hubungan pemilihan dimarkahi konjungsi: atau, tidak hanya ... tetapi juga

Contoh:

(1) Itu sebabnya, teks merupakan bahasa yang berfungsi atau bahasa yang sedang melaksanakan tugas tertentu dalam konteks situasi. (SD 1

(2) Dalam konteks Kurikulum 2013, Menteri Pendidikan dan Kebudayaan Republik Indonesia, Prof. Dr. Ir. H. Muhammad Nuh, D.E.A. menempatkan posisi bahasa Indonesia sebagai penghela ilmu pengetahuan, bahasa Indonesia tidak hanya menjadi sarana untuk mengomunikasikan ilmu pengetahuan tetapi juga sebagai sarana untuk mengembangkan dan mentransmisikan ilmu pengetahuan itu sendiri dari generasi ke generasi. (SD 1)

3) Hubungan aditif/penambahan dimarkahi konjungsi dan, tanda baca koma (,) dan diakhiri konjungsi dan, karena ... maka

Contoh:

(1) Telaah/kajian kurikulum mencakup rancang bangun silabus (seleksi dan penggolongan isi) dan metodologi (pemilihan tugas-tugas dan kegiatan-kegiatan pembelajaran), dan silabus adalah suatu spesifikasi atau perincian bahan yang akan diajarkan dalam suatu program 
bahasa berikut susunan atau urutan yang akan diajarkan. (SD 1)

(2) Register menyangkut pesan apa yang akan disampaikan (medan/field), kepada siapa pesan itu ditujukan (pelibat/tenor), dan dalam format bahasayang bagaimanakah pesan itu disampaikan (sarana/mode). (SD 1)

Hasil penelitian di atas menunjukkan hubungan antarklausa dalam kalimat majemuk setara dalam teks ilmiah meliputi hubungan perlawanan, hubungan pemilihan, dan hubungan penjumlahan/ penambahan. Hasil penelitian ini sesuai dengan apa yang dikemukakan oleh Dadjowidjoyo, dkk. (1997) yang menyatakan bahwa hubungan antarklausa dalam kalimat majemuk setara meliputi: hubungan penjumlahan, hubungan perlawanan, dan hubungan pemilihan.

Dalam kalimat majemuk setara yang terdiri atas lebih dari dua klausa, hubungan tersebut bisa berkombinasi dengan hubungan yang lain. Misalnya, antara klausa pertama dan kedua terdapat hubungan penyebaban yang ditandai dengan konjungsi karena, sedangkan antara klausa kedua dan ketiga terdapat hubungan perlawanan yang ditandai dengan konjungsi meskipun. Demikian pula dalam hubungan pemilihan bisa berkombinasi dengan hubungan penambahan. Misalnya, antara klausa pertama dan kedua terdapat hubungan pemilihan yang ditandai dengan konjungsi tidak hanya ... tetapi juga .... Sementara antara klausa kedua dan ketiga terdapat hubungan penambahan yang ditandai dengan konjungsi dan. Hubungan penambahan tidak hanya dinyatakan dengan konjungsi dan, serta, dst. Tetapi juga bisa dimarkahi dengan tanda koma (,) atau (;).

\subsubsection{Hubungan Antarklausa dalam Kalimat Majemuk Subordinatif}

Hasil penelitian menunjukkan hubungan antarklausa dalam kalimat majemuk subordinatif dalam teks ilmiah sebagai berikut.

1) Hubungan tujuan: untuk, yang ... untuk, untuk ... baik ... maupun ..., yang ... agar... baik ... maupun ...dan...

Contoh:

(1) Pembelajaran berbasis teks dirumuskan sebagai formula efektif untuk mensejajarkan pelaksanaan pendekatan ilmiah (pendekatan saintifik) sebagai "teman sejati"dalampelaksanaan Kurikulum2013.(SD 1)

(2) Selain itu, pembelajaran Bahasa Indonesia berbasis teks dimaknai sebagai pembelajaran yang mengantarkan peserta didik untuk dapat berpikir sistematis, terkontrol, empiris, dankritis. (SD 1)

(3) Capaian pembelajaran Bahasa Indonesia pada setiap multijenjang mulai pendidikan dasar sampai dengan menengah berorientasi secara konsisten untuk meningkatkan keterampilan berbahasa Indonesia peserta didik, baik secaralisan maupun tulis dengan menggunakan bahasa Indonesia yang baik dan benar. (SD 1)

(4) Dengan demikian, genre dapat didefinisikan sebagai jenis teks yang berfungsi menjadi rujukan agar suatu teks dapat dibuat lebih efektif, baik dari segi ketepatan tujuannya (tujuan sosial), maupun ketepatan pemilihan dan penyusun elemen teks, dan ketepatan dalam penggunaan unsur tata bahasanya. (SD 1) 
2) Hubungan Syarat : jika

Contoh:

(1) Peserta didik mampu berkomunikasi dengan baik jika didukung dengan emosi yang baik (Endriani, 2017). (SD 2)

3) Hubungan atributif : yang

Hubungan antarklausa dalam kalimat majemuk subordinatif yang paling produktif adalah hubungan atributif. Hubungan atributif tersebut ditandai dengan kehadiran klausa relatif yang menjadi pewatas atau atribut klausa inti.

Contoh:

(1) Perilaku-perilaku negatifyang masih dilakukan peserta didik di kelas dipengaruhi oleh beberapa factor seperti lingkungan sosial dan lingkungan keluarga. (SD 2)

(2) Emosi merupakan bentuk yang kompleks dari organisme, yang melibatkan perubahan fisik dari karakter yang luas dalam bernafas, denyutnadi, produks ikelenjar, dans ebagainya. (SD 2)

(3) Emosi individu berasal dari kecerdasan emosional yang dimiliki oleh setiap individu. (SD 2)

(4) Selaras dengan hal tersebut, maka teks didefinisikan sebagai satuan bahasa yang digunakan sebagai ungkapan suatu kegiatan sosial baik secara lisan maupun tulis dengan struktur berpikir yang lengkap (Mahsun, 2014:1). (SD 1)

(5) Tentu saja, warna pembelajaran Bahasa Indonesia menyesuaikan dengan titipan konsep pembelajaran yang ditawarkan setiap kurikulum. (SD 1)

(6) Selanjutnya, setiap subgenre tersebut memiliki tujuan sosial tersendiri yang masing-masing mengejewantahkan diri dalam berbagai jenis teks. (SD 1)

4) Hubungan penyebaban: karena ... maka

Contoh

(1) Selain itu, karena teks digunakanuntuk pernyataan suatu kegiatan sosial dengan struktur berpikir yang lengkap, maka setiap teks memiliki struktur tersendiri dengan jenis yang berbedapula. (SD 1)

Menurut Dardjowidjoyo, dkk. (1997) terdapat 13 macam hubungan antarklausa dalam kalimat mejemuk bertingkat, yaitu: hubungan waktu, hubungan syarat, hubungan tujuan, hubungan konsesif, hubungan pembandingan, hubungan penyebaban, hubungan akibat, hubungan cara, hubungan sangkalan, hubungan kenyataan, hubungan hasil, hubungan penjelasan, dan hubungan atributif. Namun, hasil penelitian hanya menemukan empat macam hubungan antarklausa dalam kalimat majemuk subordinatif dalam teks ilmiah, yaitu: (1) hubungan tujuan, (2) hubungan syarat, (4) hubungan atributif, dan hubungan penyebaban.

Faktanya, hubungan antarklausa dalam kalimat majemuk subordinatif yang terdiri atas tiga klausa atau lebih sering berkombinasi dengan hubungan yang lain. Hubungan tujuan misalnya, berkombinasi dengan hubungan atributif yang ditandai dengan konjungsi 
yang...untuk. Ada pula hubungan tujuan yang berkombinasi dengan hubungan pemilihan yang ditandai dengan pengunaan konjungsi untuk ....baik ...maupun ... dalam satu kalimat. Demikian pula dalam hubungan penyebaban ada yang berkombinasi dengan hubungan akibat yang ditandai oleh penggunaan konjungsi karena ...maka ... dalam satu kalimat.

Fakta lain adalah hubungan antarklausa dalam kalimat majemuk subordinatif yang paling produktif adalah hubungan atributif. Hubungan atributif tersebut ditandai dengan kehadiran klausa relatif yang menjadi pewatas atau atribut klausa inti.

\subsubsection{Hubungan Antarklausa dalam Kalimat Majemuk Kompleks}

Hasil penelitian menunjukkan hubungan antarklausa dalam kalimat majemuk kompleks cukup rumit karena melibatkan hubungan koordinatif dan hubungan subordinatif sekaligus.Ditemukan tujuh macam hubungan.

1) Hubungan penjelasan

Hubungan penjelasan manakala klausa penjelas memperjelas gagasan yang tertuang dalam klausa ini. Klausa penjelas biasanya terdiri atas beberapa klausa. Hubungan klausa-klausa penjelas tersebut bisa bersifat koordinatif, bisa juga bersifat subordinatif. Hubungan penjelasan ini menggunakan kopula: yaitu, adalah, seperti, bahwa

Contoh:

(1) Kemampuan komunikasi matematis meliputi beberapa indikator yaitu menghubungkan benda nyata, gambar, tabel, dan diagram ke dalam ide matematika; menjelaskan ide, situasi dan relasi matematika secara tulisan dengan benda nyata, gambar, grafik, danaljabar; dan menyatakan peristiwa sehari-hari dalam bahasa atau simbol matematis (Syarifah, etal.,2017). (SD 2)

(2) Hakikat dilaksanakannya pembelajaran Bahasa Indonesia berbasis teks itu sendiri adalah pertama: melalui teks, kemampuan berpikir siswa dapat dikembangkan; kedua: materi pembelajaran berupa teks lebih relevan dengan karakteristik Kurikulum 2013 yang menetapkan capaian kompetensi siswa yang mencakupi ketiga ranah pendidikan: sikap, pengetahuan, dan keterampilan. (SD 1)

(3) Kemampuane mosi seperti mengatasi suatu konflik, mengendalikan marah, berkonsentrasi, mengarahkan diri, berempati, dan keterampilan sosialcenderung tidak dilakukan penilaian (Putri,2107). (SD2)

(4) Berdasarkan hasil wawancara dengan salah satu guru matematika di SMP Negeri 24 Mataram, bahwa tingkah laku peserta didik masih ada yang mengganggu teman di kelas, membuat keributan di kelas, tidak memperhatikan guru pada saat guru memberikan materi, berbicara dengan teman sebangkunya, dan menghormati guru yang mereka anggap senior namun berbeda perlakuan terhadap guru PPL. (SD 2)

2) Hubungan konsesif, syarat, hasil

Hubungan konsesif terjadi manakala pernyataan yang terdapat pada klausa atribut atau penjelas tidak dapat mengubah pernyataan yang terdapat dalam klausa inti. Hasil 
penelitian ditemukan hubungan konsesif yang ditandai dengan konjungsi walaupun. Terdapat juga fakta bahwa hubungan konsesif berkombinasi dengan hubungan penyebaban yang ditandai konjungsi walaupun ... karena. Selain itu hubungan konsesif dalam kalimat majemuk kompleks juga bekombinasi dengan hubungan syarat dan hasil yang ditandai dengan kehadiran kinjungsi : meskipun ... jika ...tentu. Contoh:

(1) Meskipun peserta didik dapa tmengenali emosi diri, mengelola emosi diri sendiri, memotivasi diri sendiri, mengenali emosi orang lain, serta mampu menjaga hubungan baik dengan orang lain jika tidak memiliki pengetahuan prasyarat yang baik tentu tidak dapa tmenjawab soal matematika khususnya soal matematika yang disajikan sesuai dengan indikator kemampuan komunikasi matematis. (SD 2)

(2) Peserta didik masih aday ang menanyakan cara menyelesaikan soal tersebut meski peneliti sudah memberi tahu untuk mengerjakan sesuai dengan kemampuan, ada pesertad idik yang mengatakan sudah lupa dengan materi yang berkaitan dengan tes, dan ada peserta didik yang mengatakan bahwa matematika sulit. (SD 2)

(3) Hal tersebut menunjukkan bahwa walaupun kecerdasan emosional peserta didik tinggi maka kemampuan komunikasi matematis tertulis peserta didik tidak ikut tinggi maupun rendah karena tidak memiliki hubungan secara signifikan antara satu sama lain. (SD 2)

3) Hubungan syarat, hasil, dan penyebaban

Hubungan syarat terjadi apabila klausa penjelas menyatakan syarat terjadinya apa yang disebut dalam klausa inti. Hubungan syarat dinyatakan dimarkahi dengan konjungsi jika, apabila, bilamana, dst.. Faktanya, hubungan syarat dalam kalimat majemuk kompleks dalam teks ilmiah berkombinasi dengan hubungan hasil dan akibat yang ditandai dengan konjungsi jika... maka ...sehingga, dan penyebaban yang ditandai konjungsi jika ...karena.

Contoh:

(1) Pada saat pembelajaran matematikajika memiliki emosi yang baik maka dapatmengikuti pembelajaran dengan tertib dan mendengarkan apa yang diterangkan oleh guru sehingga pada saat guru memberikan soal matematika pesertadidik dapat menggunakan kemampuan komunikasi matematis yang mereka miliki. (SD 2)

(2) Sehingga jika peserta didik diberikan soal yang ditampilkan dalam bentuk tabel, relasi, maupun peristiwa sehari-hari kemungkinan kecil kurang bisa menjawab soal, karena kurang mampu menggunakan kemampuan komunikasi matematis peserta didik atau kemampuan prasyarat yang kurang mumpuni, hal tersebut dilihat dari fakta pada saat penelitian.(SD 2) 
4) Hubungan penyebaban

Hubungan penyebaban terjadi apabila klausa penjelas menyatakan sebab atau alasan terjadinya sesuatu yang dinyatakan dalam klausa utama. Hubungan tersebut dinyatakan dengan konjungsi karena.

Contoh:

(1) Peserta didik yang mempunyai kecerdasa nemosional akan lebih bisa mengendalikan dirinya saat menghadapi masalah dalam belajar khususnya dalam belajar matematika, karena kecerdasan emosional terdiri dari indikator-indikator di antaranya: mengenali emosi diri, mengelola emosi diri sendiri, memotivasi diri sendiri, mengenali emosi orang lain, dan membina hubungan dengan orang lain.(SD 2)

(2) Hal yang berbeda terletak pada KD Kurikulum 2013 yang sepenuhnya berbasis pada teks dengan struktur berpikir antarsatu teks dengan teksy ang lainnya berbeda, karena fungsi sosial yang diemban teks berbeda. (SD 1)

5) Hubungan atributif

Hubungan atributif terjadi apabila klausa penjelas atau atribut membatasi atau menerangkan subjek klausa utama. Hasil penelitian menunjukkan bahwa hubungan atribut dalama klaimat komp[eks dimarkahi konjungsi yang.

Contoh:

(1) Nilai kemampuan komunikasi matematis biasanya hanya ditunjukkan dalam bentuk angka yang tinggi rendahnya menunjukkan seberapa jauh peserta didik dapat menghubungkan benda nyata, gambar, tabel, dan diagram ke dalam ide matematika;menjelaskanide, situasi,danrelasimatematikasecaratulisandenganbend anyata, gambar, grafik,dan aljabar; dan menyatakan peristiwa sehari-hari dalam bahasa atau simbol matematis. (SD 2)

6) Hubungan akibat

Hubungan akibat terjadi apabila klausa penjelas menyatakan akibat dari pernyataan yang terdapat dalam klausa inti. Hasil penelitian menemukan hubungan akibat yang ditandai konjungsi sehingga. Temuan lain adalah hubungan akbibat dapat juga berkombinasi dengan hubungan perlawanan yang ditandai dengan konjungsi , namun ...sehingga

Contoh:

(1) Selainitu, kecerdasan emosional tidak diajarkan secara khusus disekolah atau tidak tercatat dalam dokumen rapor, seperti nilai-nilai pelajaran ataupun keterampilan-keterampilan lainnya sehingga tidak ada hubungan secara langsung terhadap peningkatan kemampuan komunikasi matematis. (SD 2)

(2) Peserta didik yang mampu mengendalikan emosi pada saat pembelajaran matematika seperti mengikuti pembelajaran matematika 
yang tertib namun tidak mencermati pembelajaran matematika, sehingga kecerdasan emosional peserta didik tidak memiliki hubungan secara signifikan dengan kemampuan komunikasi matematis. (SD 2)

7) Hubungan tujuan

Hubungan tujuan terjadi apabila klausa penjelas menyatakan tujuan pernyataan yang dinyatakan dalam klausa inti. Hubungan tujuan yang ditemukan dalam penelitian ini adalah hubungan tujuan yang berkombinasi dengan hubungan akibat. Hubungan ini ditandai dengan konjungsi untuk ... maka.

Contoh:

(1) Untuk memahami dan menguasai informasi dan teknologi yang berkembang pesat khususnya peserta didik, maka diperlukan penguasaan pembelajaran matematika sejak dini. (SD 2)

\section{SIMPULAN DAN SARAN}

\subsection{Simpulan}

Berdasarkan hasil penelitian di atas dapat ditarik beberapa simpulan sebagai berikut.

\subsection{Struktur Kalimat Majemuk Bahasa Indonesia dalam Teks Ilmiah}

Struktur kalimat majemuk dalam teks ilmiah terdiri atas tiga macam, yaitu (1) struktur kalimat majemuk koordinatif, (2) struktur kalimat majemuk subordinatif, dan (3) struktur kalimat majemuk kompleks.

1) Struktur Kalimat Majemuk Koordinatif dalam Teks Ilmiah

Kalimat majemuk koordinatif dalam teks ilmiah ada yang terdiri atas dua klausa dan ada pula yang terdiri atas tiga klausa. Struktur kalimat majemuk koordinatif yang terdiri atas dua klausa pada umumnya berpola S P Komp + S P Komp. Struktur kalimat majemuk koordinatif yang terdiri atas tiga klausa juga memiliki pola yang sama dengan kalimat majemuk koordinatif yang terdiri atas dua klausa. Ada klausa yang berpola $\mathbf{S} \mathbf{P}+\mathbf{S} \mathbf{P}+\mathbf{S} \mathbf{P}$ Komp, dan ada pula yang berpola $\mathbf{S} \mathbf{P}$ Komp Ket + S P Komp + S P Komp Ket.

2) Struktur Kalimat Majemuk Subordinatif dalam Teks ilmiah

Kalimat majemuk subordinatif dalam teks ilmiah ada yang terdiri atas dua klausa dan ada pula yang terdiri atas tiga klausa.Strukutur kalimat subordinatif yang terdiri atas dua klausa terdiri atas dua tipe, yaitu tipe 1: berpola $\mathbf{S}$ (s $\mathbf{P}$ Komp) + $\mathbf{P}$ Komp Ket dan tipe 2: berpola $\mathbf{S} \mathbf{P}$ Komp + Ket $(\mathrm{P}$ Komp ).

Struktur kalimat majemuk subordinatif yang terdiri atas tiga klausa terbagi atas tiga tipe, yaitu Tipe 1 : berpola $\mathbf{S} \mathbf{P} \mathbf{K o m p}_{(\mathbf{P}+0)}+\mathbf{K e t}_{(\mathbf{P}+}$ Komp), Tipe 2 : berpola $\mathbf{S}_{(\mathbf{S} \text { P Ket) }}+\mathbf{P} \mathbf{O}+$ Ket (Ket P Komp), danTipe 3 berpola: $S_{(S \text { P Komp) }}+$ P Komp + P Komp 
3) Struktur Kalimat Majemuk Kompleks dalam Teks Ilmiah

Struktur kalimat majemuk kompleks dalam teks ilmiah terdiri atas tujuh tipe.

Tipe 1: berpola $S_{(\text {P Komp })}+$ P O + P O + P Komp

\section{Tipe 2 : berpola Ket + S P O Ket + P O Ket + P O Ket ${ }_{(\mathbf{P}}$ o $)+$ P Komp + P Komp}

Tipe 3 : berpola S P Komp + Ket $(\mathbf{P}$ Komp + Ket (P Komp)) + S P Komp (P O + P o $+\mathbf{P O}+\mathbf{P} \mathbf{O}+\mathbf{P} \mathbf{O})$

Tipe 4 : berpola : S P Komp + Ket S P + S P Komp + P Komp + P Komp

Tipe 5 : berpola : $\mathbf{P}+\mathbf{P}+\mathbf{O}+\mathbf{P}+$ Komp + Komp

Tipe 6 : berpola : $S($ P O + P O + P O + P O + P O ) + P O + P O (s + P Komp)

Tipe 7 berpola :S ( P O + P O+P + P O+P) + S P Komp

\subsubsection{Hubungan Antarklausa dalam Kalimat Majemuk Bahasa Indonesia dalam Teks Ilmiah}

Alimat majemuk dalam bahasa Indonesia terbagi atas tiga macam, yaitu kalimat majemuk koordinatif, kalimat majemuk subordinatif, dan kalimat majemuk kompleks.

1) Hubungan antarklausa dalam kalimat majemuk koordinatif

Terdapat tiga macam hubungan semantik antarklausa dalam kalimat majemuk bahasa Indonesia dalam teks ilmiah, yaitu: hubungan perlawanan, pemilihan dan penjumlahan/penambahan.

2) Hubungan antarklausa dalam kalimat majemuk subordinatif

Hasil penelitian menemukan empat macam hubungan antarklausa dalam kalimat majemuk subordinatif dalam teks ilmiah, yaitu: (1) hubungan tujuan, (2) hubungan syarat, (4) hubungan atributif, dan hubungan penyebaban. Faktanya, hubungan antarklausa dalam kalimat majemuk subordinatif yang terdiri atas tiga klausa atau lebih sering berkombinasi dengan hubungan yang lain. Hubungan antarklausa dalam kalimat majemuk subordinatif yang paling produktif adalah hubungan atributif.

3) Hubungan antarklausa dalam kalimat majemuk kompleks

Hasil penelitian menunjukkan hubungan antarklausa dalam kalimat majemuk kompleks dalam teks ilmiah cukup rumit karena melibatkan hubungan koordinatif dan hubungan subordinatif sekaligus.Hasil penelitian menemukan tujuh macam hubungan antarklausa dalam kalimat majemuk kompleks, yaitu: (1) hubungan penjelasan,(2) hubungan konsesif, (3) hubungan syarat, (4) hubungan penyebaban,(5) hubungan atributif ,(6) hubungan akibat, dan (7) hubungan tujuan. Hubungan antarklausa dalam kalimat majemuk kompleks tidak bersifattunggal, melainkan hubungan tersebut bekombinasi dengan hubungan lain sesuai dengan tingkat kompleksitas hubungan dan jumlah klausa yang terdapat dalam kalimat tersebut.

\subsection{Saran}

Hasil analisis data kalimat majemuk dalam teks ilmiah ternyata struktur dan hubungan antarklausa dalam kalimat majemuk cukup rumit.Kalimat majemuk yang dicontohkan 
dalam buku-buku tata bahasa Indonesia belum mewakili struktur kalimat majemuk dalam berbagai ranah pemakaian bahasa. Struktur kalimat majemuk yang terdapat dalam teks ilmiah pasti berbeda dengan struktur kalimat majemuk yang terdapat dalam teks narasi atau fiksi.Struktur kalimat majemuk dalam teks undang-undang atau hukum pasti punya kekahasan tersendiri. Oleh sebab itu peneliti menyarankan beberapa hal sebagai berikut.

(1) Kepada peneliti lain yang berminat dalam kajian sintaksis untuk melakukan penelitian lanjutan struktur kalimat majemuk dalam ranah pemakaian bahasa yang lain seperti yang dikemukakan di atas.

(2) Penulisan buku tata bahasa atau buku ajar sedapat mungkin data atau contoh kalimat berbasis penggunaan bahasa dalam berbagai ranah, hindari contoh kalimat yang berdasarkan intuisi.

\section{DAFTAR PUSTAKA}

Alisjahbana, Sutan Takdir. 1978. Tata Bahasa Baru Bahasa Indonesia, jilid 1. Jakarta: Dian Rakyat.

Fokker, A.A. 1980. Pengantar Sintaksis Indonesia. Penerjemah: Djonhar. Jakarta: Pradnya Paramita.

Haegeman, Liliane. 1992. Introduction to Government and Binding Theory. Oxford UK \& Cambridge USA: Blackwell.

Jehane, Hendrikus. 1996. "Inkorporasi dengan Pelesapan Verba dalam bahasa Indonesia." Dalam Linguistika, edisi Keempat, Maret 1996. Denpasar: Universitas Udayana. Halaman 61-69.

Jehane, Hendrikus. 1998. "Struktur Argumen dan Peran Tematik Kalimat Bahasa Indonesia." Dalam Guru Bahasa, Tahun II, Nomor 6, Desember 1998.

Jehane, Hendrikus. 2003. "Relasi Gramatikal Bahasa Indonesia." Jurnal Pendidikan Bahasa, Volume 8, Nomor 14, November 2003.

Jehane, Hendrikus. 2006. "Posisi Keterangan dalam Kalimat Bahasa Indonesia”.Jurnal Pendidikan Bahasa dan Sastra. Volume 10, nomor 20, November 2006.

Jehane, Hendrikus. 2007. "Kontroversi Seputar Diatesis Bahasa Indonesia" Jurnal Pendidikan Bahasa dan Sastra. Volume 11, no.20, Juni 2007.

Kaswanti Purwo, Bambang (ed.1987. "Subjek-Predikat: Sebuah Tinjauan." Makalah (belum terbit).

Keraf, Gorys. 1996. Tata Bahasa Indonesia. Ende: Nusa Indah.

Kridalaksana, Harimurti. 1988. Beberapa Prinsip Perpaduan Leksem dalam Bahasa Indonesia. Yogyakarta: Kanisius. 
Kridalaksana, Harimurti. 1992. Pembentukan Kata dalam Bahasa Indonesia. Jakarta: Gramedia.

Parera, Jos Daniel. 1993. Sintaksis. Jakarta: Gramedia Pustaka Utama.

Ramlan, M. 1987. IImu Bahasa Indonesia: Sintaksis. Yogyakarta: C.V. Kayono.

Rustiati, 2013. Kalimat Majemuk Kompleks. Artikel Ilmiah dimuat di Jurnal Widya Warta No. 02 Tahun XXXV II/ Juli 2013.

Samsuri.1985. Tata Kalimat Bahasa Indonesia. Jakarta: Sastra Husada.

Widjojo, Soendjono, dkk. 1997. Tata Bahasa Baku Bahasa Indonesia. Jakarta: Balai Pustaka.

Sugono, Dendy. 1995. Pelesapan Subjek dalam Bahasa Indonesia. Jakarta: Pusat Pembinaan dan pengebangan Bahasa Departemen Pendidikan dan kebudayaan.

Nurwardani, Paristiyanti, dkk. 2016. Buku Ajar Mata Kuliah Wajib Umum Bahasa Indonesia: Ekspresi Akademik. Jakarta: Direktorat Jenderal Pembelajaran dan Kemahasiswaan Kementerian Riset, Teknologi, dan Pendidikan Tinggi.

Vehaar, J.W.M. 1996. Asas-asas Linguistik. Yogyakarta: Gadjah Mada University Press. 